\title{
UNDERSTANDING OF DATA STRUCTURES
}

\author{
Novialindra Chika Salsabila \\ 195120005 \\ Fakultas Komputer \\ novialindra.students@umitra.ac.id
}

\begin{abstract}
Dalam istilah ilmu komputer, sebuah struktur data adalah cara penyimpanan, penyusunan dan pengaturan data di dalam media penyimpanan komputer sehingga data tersebut dapat digunakan secara efisien
\end{abstract}

Struktur data merupakan sesuatu yang berfungsi untuk mengorganisasikan data sedemikian rupa sehingga implementasi ( penerapan ) atau pemeliharaan logika program menjadi lebih terstruktur. " isi abstrak mewakili isi pembahasan ( Section 01 ) "Secara umum program adalah kumpulan intruksi atau perintah yang disusun sedemikian rupa sehingga mempunyai urutan logika yang tepat untuk menyelesaikan suatu persoalan.

Turbo pascal merupakan salah satu aplikasi program. Selanjutnya adalah algoritma yang merupakan jantung semua program yang merupakan urutan langkah sistematis dan dirancang untuk menyelesaikan suatu masalah spesifik dan dengan usaha yang paling minimal

Kata Kunci : Penerimaan dan Pengeluaran Kas. 


\section{A. PENDAHULUAN}

Materi Kuliah Section 01

Membahas Tentang Pengertian

Struktur Data :

\section{Latar Belakang}

Pemograman dalam struktur

data ada beberapa macam.

Salah satunya adalah

pemograman $\mathrm{C}++$. Dalam

pemograman ini biasanya

menggunakan variable Array,

Struktur dan Linked List

Makalah ini membahas tentang

3 variabel tersebut dimana

ketiga variable mempunyai ciri

dan umum yang berbeda sesuai

dengan tipe file yang di

gunakan pembaca. Seperti

array yang menggunakan satu

dimensi dan dua dimensi serta

3 dimensi dimana sangat

berbeda dengan struktur yang

menggunakan tingkatan

prosedur.

Pemograman ini merupakan

pemograman yang berbeda dari

pemograman lainnya misalnya

VB, Delphi atau Pascal namun perbedaan juga tidak begitu

signifikan pada pemograman

pascal

\section{B. PEMBAHASAN / STUDI KASUS PENGERTIAN STRUKTUR DATA}

:

Dalam istilah ilmu komputer, sebuah struktur data adalah cara penyimpanan, penyusunan dan pengaturan data di dalam media penyimpanan komputer sehingga data tersebut dapat digunakan secara efisien.Sedangkan Data adalah representasi dari fakta dunia nyata. Fakta atau keterangan tentang kenyataan yang disimpan, direkam atau direpresentasikan dalam bentuk tulisan, suara, gambar, sinyal atau simbol.

Konstanta digunakan untuk menyatakan nilai tetap sedangkan variable digunakan dalam program untuk menyatakan nilai yang dapat berubah-ubah selang eksekusi berlangsung.

Ada empat istilah data, yaitu: 
A. Tipe data adalah jenis atau macam data di dalam suatu variable dalam bahasa pemrograman.

B. Objek data mengacu kumpulan elemen, D (domain).

C. Representasi data : Suatu mapping dari struktur data 'd' ke suatu set ke struktur data 'e' $(\mathrm{d}===\mathrm{e})$ misal bolean di representasikan dalam 0 dan 1.

D. Struktur data biasa dipakai untuk mengelompokan beberapa informasi yang terkait menjadi sebuah kesatuan.

Dalam teknik pemrograman, struktur data berarti tata letak data yang berisi kolom-kolom data, baik itu kolom yang tampak oleh pengguna (user) atau pun kolom yang hanya digunakan untuk keperluan pemrograman yang tidak tampak oleh pengguna.Setiap baris dari kumpulan kolom-kolom tersebut dinamakan catatan (record). Lebar kolom untuk data dapat berubah dan bervariasi. Ada kolom yang lebarnya berubah secara dinamis sesuai masukan dari pengguna, dan juga ada kolom yang lebarnya tetap. Dengan sifatnya ini, sebuah struktur data dapat diterapkan untuk pengolahan database (misalnya untuk keperluan data keuangan) atau untuk pengolah kata (word processor) yang kolomnya berubah secara dinamis. Contoh struktur data dapat dilihat pada berkas-berkas lembarsebar (spreadsheet), pangkal-data (database), pengolahan kata, citra yang dipampat (dikompres), juga pemampatan berkas dengan teknik tertentu yang memanfaatkan struktur data.

Secara garis besar type data dapat dikategorikan menjadi:

\section{Type data sederhana.}

Type data sederhana tunggal, misalnya Integer, real, boolean dan karakter.

Type data sederhana majemuk, misalnyaString

\section{Struktur Data, meliputi:}

Struktur data sederhana, misalnya array dan record.

Struktur data majemuk, yang terdiri dari:
A. Linier :
Stack,
Queue, 
sertaList

dan

Multilist

B. Non Linier

: Pohon

Biner dan

Graph

Pemakaian struktur data yang tepat didalam proses pemrograman akan menghasilkan algoritma yang lebih jelas dan tepat, sehingga menjadikan program secara keseluruhan lebih efisien dan sederhana.

Struktur data yang standar yang biasanya digunakan dibidang informatika adalah:

A. List linier (Linked List) dan variasinya

B. Multilist

C. Stack (Tumpukan)

D. Queue (Antrian)

E. Tree ( Pohon)

F. Graph ( Graf)

\section{B. PEMBUATAN STRUKTUR}

\section{DATA}

Untuk membuat menjadi struktur data, kita harus melakukan dulu aktivitas terhadap objek data, yaitu :
- v Mendeskkripsikan kumpulan operasi sah yang diterapkan ke elemen-elemen objek data.

- v Menunjukan mekanisme kerja operasi-operasi.

Objek data integer ditambah operasi $(+,-, *$, /, mod ,cell, floor , $<$, >) dan operasi-operasi lain yang memanipuasi objek data integer menyatakan struktur data.

Struktur data $=$ Objek data $+\{$ Operasi manipulasi \}.

Tahap pembuatan struktur data adalah

$\varnothing$ Tahap pertama: Spesifikasi

Pendeskripsian / spesifikasi struktur data menyatakan apa yang dapat dilakukan struktur data, bukan cara penerapannya.

Spesifikasi dapat dilakukan dengan dua cara, yaitu :

- Spesifikasi secara formal

- Spesifikasi secara informal

$\varnothing$ Tahap kedua : Implementasi

Implementasi menyatakan cara penerapan struktur data dengan struktur data yang telah ada.Implementasi struktur data adalah 
proses pendefinisian tipe data abstrak sehingga semua operasi dapat dieksekusi computer. Implementasi struktur penyinpanan item-item data serta algoritma-algoritma untuk implementasi operasi-operasi sehingga menjamin terpenuhinya karakteristik struktur data, relasi item-item data atau invariant pada struktur data itu.

\section{$\varnothing$ Tahap ketiga : Pemrograman}

Pemrograman terstruktur adalah penerjemahan menjadi pernyataan di bahasa pemrograman tertentu. Prosesnya terdiri dari :

A. Deklarasi yang mendefinisikan objek-objek data dan hubungannya...

B. Pembuatan prosedur / rutin untuk operasi-operasi dasar yang menjaga invariant pada struktur data itu .

Sesuai dengan relasi yang didefinisikan di spesifikasi perancangan harus memilih tipe-tipe data yang telah ada untuk merepresentasikan struktur data.

Struktur data di bangun menggunakan fasilitas pembentukan atau pembuatan struktur data yang disediakan bahasa seperti array, record, dan sebagainya atau yang telah di buat seperti stack, queue, atau himpunan menggunakan linked list. Pembuatan struktur data adalah pembentukan tipe data lengkap yang mempunyai empat property berikut :

1. Nama : Identifier tipe data

2. Domain: Domain / himpunan semesta nilai di tipe data

3. Konstanta (penyebutan anggota-anggotanya) : Cara penyebutan anggota- anggota tipe data

4. Operasi-operasi terhadap tipe data itu (operator) : Daftar operasi terhadap anggota tipe data sehingga kelakuan objek data sesuai spesifikasi.

\section{ARRAY}

\subsection{Pengertian Array}

Array atau larik didefinisikan sebagai pemesanan alokasi memory berurutan.definisi ini kurang tepat, karena terjadi kerancuan antara struktur data dan representasinya.Memang benar array hampir selalu di implementasikan menggunakan memory berurutan tapi tidak selalu demikian.

Semua elemem array bertipe sama. Array cocok untuk organisasi 
kumpulan data homogen yang ukuran atau jumlah elemen maksimumnya telah diketahui dari awal.

Homogen adalah bahwa setiap elemen dari sebuah array tertentu haruslah mempunyai tipe data yang sama.

\subsection{Karakteristik Array}

a) Mepunyai batasan dari pemesanan alokasi memori (bersifat statis)

b) Mempunyai tipe data sama (bersifat homogen)

c) Dapat diakses secara acak

\subsection{Deklarasi Array}

Ada tiga hal yang harus di ketahui dalam mendeklarasikan array, yaitu :
a) Type data array
b) Nama variable array
c) Subkrip / index array

Contoh deklarasi dari array adalah sebagai berikut : int $\mathrm{A}[5]$; artinya variabel $\mathrm{A}$ adalah kumpulan data sebanyak 5 bilangan bertipe integer.

\subsection{Jenis Array}

1. Array Dimensi Satu

Deklarasi : Type_Data Nama_Variabel [index]

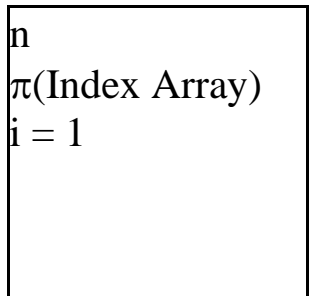

Rumus untuk menentukan jumlah elemen dalam array adalah :

$\pi=$ Perkalian dari index sebelumnya (untuk arraybdimensi dua dan tiga).

Pemetaan (Mapping) Array Dimensi

$\underline{\text { Satu Ke Storage }}$

Rumus : @ A $[\mathrm{i}]=\mathrm{B}+(\mathrm{i}-1) *$ $\mathrm{L}$

Dimana : @A[i] : Posisi array yang dicari

$$
\text { B : Posisi }
$$

awal index di memori computer

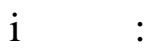

Subkrip atau index array yang di cari

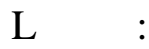

Ukuran atau besar memori suatu tipe data

2. Array Dimensi Dua 
Deklarasi: Type_Data Nama_Variabel

[index1] [index2]

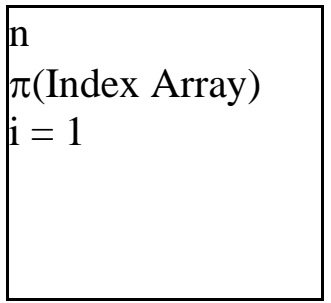

Menentukan jumlah elemen

dalam array dimensi dua :

$\pi=$ Perkalian dari statemen

sebelumnya

Pemetaan (Mapping) Array Dimensi

Dua Ke Storage

Terbagi dua cara pandang

(representasi) yang berbeda :

Secara kolom per kolom (coloumn major order / CMO)

$$
\begin{aligned}
& @ \mathrm{M}[\mathrm{i}][\mathrm{j}]=\mathrm{M}[0][0]+\{(\mathrm{j}-1) \\
& * \mathrm{~K}+(\mathrm{i}-1)\} * \mathrm{~L}
\end{aligned}
$$

Secara baris per baris (row major order / RMO)

$$
\begin{aligned}
& @ \mathrm{M}[\mathrm{i}][\mathrm{j}]=\mathrm{M}[0][0]+\{(\mathrm{i}-1) \\
& * \mathrm{~N}+(\mathrm{j}-1)\} * \mathrm{~L}
\end{aligned}
$$

Keterangan :

$@ \mathrm{M}[\mathrm{i}][\mathrm{j}]=$ Posisi array yang di cari, $\mathrm{M}[0][0=$ Posisi alamat awal index array, $\mathrm{i}=$ Baris, $\mathrm{j}=$ Kolom, $\mathrm{L}=$ Ukuran memory type data, $\mathrm{K}=$ Banyaknya elemen per kolom, $\mathrm{N}=$ Banyaknya elemen per baris.
3. Array Dimensi Tiga

Deklarasi : type_Data

Nama_Variabel

[index1][index2][index3]

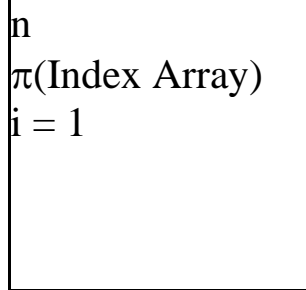

Menentukan jumlah elemen dalam array dimensi tiga :

$\pi=$ Perkalian dari statemen

sebelumnya

Pemetaan (Mapping) Array

Dimensi Tiga Ke Storage

$$
\begin{aligned}
& \text { Rumus : @ M }[\mathrm{n}][\mathrm{m}][\mathrm{p}]= \\
& \mathrm{M}[0][0][0]+\{((\mathrm{n}-1) *(\text { index } 1))+ \\
& ((\mathrm{m}-1) * \quad(\text { index } 2))+((\mathrm{p}-1) * \\
& (\text { index } 3)\} * \mathrm{~L}
\end{aligned}
$$

\section{TRIANGULAR ARRAY (ARRAY}

\section{SEGI TIGA)}

Triangular array dapat merupakan

Upper Triangular (seluruh elemen di bawah diagonal utama $=0$ ), ataupun Lower Triangular (seluruh elemen di atas diagonal utama $=0$ ).

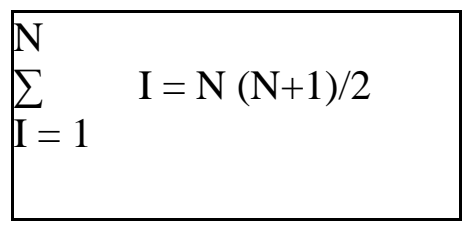




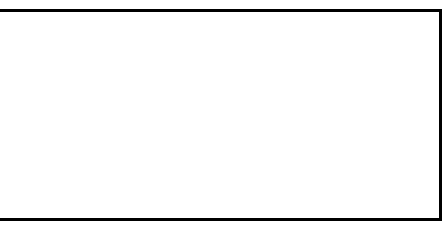

Dalam array Lower Triangular dengan $\mathrm{N}$ baris, jumlah maksimum elemen $<>$ 0 , tidak lebih dari

SPERSE ARRAY (ARRAY JARANG)

Suatu array yang sangat banyak elemen nol-nya
2. Pengambilan nilai elemen dari posisi tertentu di array.

Operasi-operasi dasar terhadap array secara keseluruhan adalah :

1. Operasi penciptaan

2. Operasi penghancuran

3. Oparasi pemrosesan traversal

4. Operasi pencarian (table look-up)

5. Operasi sorting

\subsection{Penciptaan Dan Penghancuran}

\subsection{Operasi Dasar Pada Array}

Operasi terhadap elemen di array dilakukan dengan pengaksesan langsung. Nilaidi masing-masing posisi elemen dapat diambil dan nilai dapat disimpan tanpa melewati posisi-posisi lain.

Terdapat dua tipe operasi, yaitu :

1. Operasi terhadap satu elemen / posisi dari array

2. Operasi terhadap array sebagai keseluruhan.

Dua operasi paling dasar terhadap satu elemen / posisi adalah :

1. Penyimpanan nilai elemen ke posisi tertentu di array.
Operasi penciptaan biasa

disebut inisialisasi.Operasi ini untuk mempersiapkan struktur data untuk operasi-operasi berikutnya.Operasi penghancuran menyatakan ketidak berlakuan struktur data atau membebaskan memory, menyerahkan memory ke manajemen memory agar dapat di pergunakan keperluan lain.Operasi penghancuran penting terutama bila struktur data di implementasikan secara dinamis menggunakan pointer

\subsection{Penyimpanan Dan Pengambilan Nilai}

Biasanya bahasa pemrograman menyediakan sintaks tertentu untuk 
penyimpanan dan pengambilan nilai elemen pada posisi tertentu di array. Contoh :

$\mathrm{A}[10]=78$, berarti penyimpanan nilai 78 ke posisi ke-10 dari array A. $\mathrm{C}=\mathrm{A}[10]$, berarti pengambilan nilai elemen posisi ke-10 dari array A.

\subsection{Pemrosesan Transversal}

Operasi pemrosesan transversal adalah pemrosesan mengolah seluruh elemen secara sistematik.

\subsection{Pencarian Di Array (Table} Look-Up)

Pencarian di array (table look-up) adalah proses pencarian suatu nilai di array. Klasifikasi pencarian di array adalah :

1) Pencarian sekuen (sequential searching),yaitu:

a. Tanpa Boolean, terbagi:

- Tanpa sentinen

- Dengan sentinen

b. Menggunakan boolean

2) Pencarian secara biner /

dikotom (binary = dichotomy searching).

\subsection{Pengurutan Array}

Pengurutan atau sorting adalah proses yang paling sering di lakukan dalam pengolahan data.pengurutan di bedakan menjadi dua, yaitu :

a. Pengurutan internal Pengurutan dilakukan terhadap sekumpulan data di media memory internal komputer dimana data dapat di akses elemennya secara langsung.

b. Pengurutan eksternal Pengurutan data di memory sekunder.Biasanya data bervolume besar sehingga tidak mampu dimuat semuanya di memori utama.

\subsection{Keunggulan Dan Kelemahan Array}

$\varnothing$ Keunggulan array adalah sebagai berikut :

1. Array sangat cocok untuk pengaksesan acak. Sembarang elemen di array dapat diacu secara langsung tanpa melalui elemen-elemen lain.

2. Jika berada di suatu lokasi elemen, maka sangat mudah menelusuri ke elemen-elemen tetangga, baik elemen 
pendahulu atau elemen penerus 3

3. Jika elemen-elemen array adalah nilai-nilai independen dan seluruhnya harus terjaga,maka penggunaan penyimpanannya sangat efisien.

$\varnothing$ Kelemahan array adalah sebagai berikut :

Array mempunyai fleksibilitas rendah, sehingga tidak cocok untuk berbagai aplikasi karena array mempunyai batasan sebagai berikut :

1. Array harus bertipe homogen. Kita tidak dapat mempunyai array dimana satu elemenadalah karakter, elemen lain bilangan, dan elemen lain adalah tipe-tipe lain

2. Kebanyakan bahasa pemrograman mengimplementasikan array statik yang sulitdiubah ukurannya di waktu eksekusi. Bila penambahan dan pengurangan terjaditerus- menerus, maka representasi statis

- Tidak efisien dalam

penggunaan memori

- Menyiakan banyak waktu

komputasi

- Pada suatu aplikasi, representasi statis tidak dimungkinkan

Bila penambahan dan pengurangan terjadi terus menerus, maka representasi statis (array):

1. Tidak efisien dalam penggunaan memory

2. Menyiakan banyak waktu komputasi

Pada suatu aplikasi, representasi statis tidak di mungkinkan

C. ID SECURITY

QWTD4452377-ASP-5244166

D. KESIMPULAN

Struktur data merupakan salah satu bahan dasar pembuatan program. Pemakaian struktur data yang tepat di dalam proses pemrograman, akan menghasilkan algoritma yang jelas dan tepat sehingga menjadikan program secara keseluruhan lebih sederhana. Array merupakan bagian dari 
struktur data yaitu termasuk kedalam struktur data sederhana yang dapat di definisikan sebagai pemesanan alokasi memory sementara pada komputer.Apabila kita membuat program dengan data yang sudah kita ketahui batasnyamaka kita menggunakan Array (type data statis), namun apabila datanya belum kita ketahui batasnya maka gunakan pointer (type data dinamis )

\section{E. DISKUSI}

- Saya bersama teman saya bernama Ersha mendiskusikan tentang contoh ini dengan sangat baik Hasil diskusi dari materi ini adalah bahwa Struktur data harus dipelajari dengan baik agar pada saat membuat program lebih mudah karena manfaat struktur data untuk Merapikan data, agar data yang tersimpan mudah diakses, diubah, dikeluarkan, dihapus, struktur data memiliki beragam jenis tergantung kebutuhan,

- Menurut defenisinya, array (larik) adalah sebuah variabel yang dapat menyimpan lebih dari satu nilai sejenis (memiliki tipe data yang sama).

Bagaimana cara mendeklarasikan sebuah array/larik di python?
- Sama seperti pada bahasa lain, list di Python merupakan sekumpulan elemen atau objek. Tapi, kita bisa memiliki bermacam-macam jenis elemen dalam satu list. Misal, string, integer, objek, list lain, maupun struktur data lain. Karakteristik utama dari list ini adalah, memiliki index dan mutable (bisa di-otak-atik). List di python menggunan zeroth based index. Contoh :

list $1=[]$ \# deklarasi list list1.append('elemen_0') \#menambah 1 buah elemen di ujung list print list1[0]

- Pendeklarasian variabel pada Python menggunakan [] "kurung siku" contoh: listnya= [<elemen_0>, <elemen_1>] atau listnya = [] untuk array yang elemennya dalam posisi kosong.

<elemen_0> bisa diganti dengan tipe data seperti integer, string atau tipe data lain. Contoh: listnya $=[1,2]$ atau listnya [1, 2, 3, 4, 5], lalu untuk string listnya = ['Ini adalah string 1', 'Ini adalah string 2']. 


\section{F. REFERENCE}

[1] O. M. Febriani and A. S. Putra, "Sistem Informasi Monitoring Inventori Barang Pada Balai Riset Standardisasi Industri Bandar Lampung," J. Inform., vol. 13, no. 1, pp. 90-98, 2014.

[2] A. S. Putra, "Paperplain: Execution Fundamental Create Application With Borland Delphi 7.0 University Of Mitra Indonesia," 2018.

[3] A. S. Putra, "2018 Artikel Struktur Data, Audit Dan Jaringan Komputer," 2018.

A S Putra, "ALIAS MANAGER USED IN DATABASE DESKTOP STUDI CASE DB DEMOS."

A. S. Putra, "COMPREHENSIVE SET OF PROFESSIONAL FOR DISTRIBUTE COMPUTING."

[6] A. S. Putra, "DATA ORIENTED RECOGNITION IN BORLAND DELPHI 7.0."

[7] A. S. Putra, "EMBARCADERO DELPHI XE 2 IN GPUPOWERED FIREMONKEY APPLICATION."

[8] A. S. Putra, "HAK ATAS KEKAYAAN INTELEKTUAL DALAM DUNIA TEKNOLOGY BERBASIS REVOLUSI INDUSTRI 4.0.”

[9] A. S. Putra, "IMPLEMENTASI PERATURAN

PERUNDANGAN UU. NO 31 TAHUN 2000 TENTANG DESAIN INDUSTRI BERBASIS INFORMATION TECHNOLOGY." 
[10] A. "IMPLEMENTATION PARADOX DBASE."

A.

$S$. "IMPLEMENTATION TRADE SECRET STUDY SAMSUNG MOBILE PHONE."

[12] A.

"IMPLEMENTATION

PATENT FOR APPLICATION WEB BASED CASE STUDI WWW. PUBLIKLAMPUNG. COM."

[13] A. "IMPLEMENTATION SYSTEM FIRST TO INVENT IN DIGITALLY INDUSTRY."

[14] A. S. Putra, "MANUAL REPORT \& INTEGRATED DEVELOPMENT

ENVIRONMENT BORLAND DELPHI 7.0."

[15] A. S. Putra, "PATENT AS RELEVAN SUPPORT RESEARCH."

[16] A. S. Putra, "PATENT FOR RESEARCH STUDY CASE OF APPLE. Inc."

[17] A. S. Putra, "PATENT PROTECTION FOR APPLICATION INVENT."

[18] A. S. Putra, "QUICK REPORT IN PROGRAMMING."

[19] A. S. Putra, "REVIEW CIRCUIT LAYOUT COMPONENT

REQUIREMENT ON ASUS NOTEBOOK."

[20] A. S. Putra, "REVIEW TRADEMARK PATENT FOR INDUSTRIAL TECHNOLOGY BASED 4.0."

[21] A. S. Putra, "TOOLBAR
COMPONENT PALLETTE IN OBJECT ORIENTED PROGRAMMING."

[22] A. S. Putra, "WORKING DIRECTORY SET FOR PARADOX 7."

[23] A. S. Putra, "ZQUERY CONNECTION

IMPLEMENTED

PROGRAMMING STUDI CASE PT. BANK BCA Tbk."

[24] A. S. Putra, D. R. Aryanti, and I. Hartati, "Metode SAW (Simple Additive Weighting) sebagai Sistem Pendukung Keputusan Guru Berprestasi (Studi Kasus: SMK Global Surya)," in Prosiding Seminar Nasional Darmajaya, 2018, vol. 1, no. 1, pp. 85-97.

[25] A. S. Putra and O. M. Febriani, "Knowledge Management Online Application in PDAM Lampung Province," in Prosiding International conference on Information Technology and Business (ICITB), 2018, pp. 181-187.

[26] A. S. Putra, O. M. Febriani, and B. Bachry, "Implementasi Genetic Fuzzy System Untuk Mengidentifikasi Hasil Curian Kendaraan Bermotor Di Polda Lampung," SIMADA (Jurnal Sist. Inf. dan Manaj. Basis Data), vol. 1, no. 1, pp. 21-30, 2018.

[27] A. S. Putra, H. Sukri, and K. Zuhri, "Sistem Monitoring Realtime Jaringan Irigasi Desa (JIDES) Dengan Konsep Jaringan Sensor Nirkabel," IJEIS (Indonesian J. Electron. Instrum. Syst., vol. 8, no. 2, pp. 221-232. 
[28] D. P. Sari, O. M. Febriani, and A. S. Putra, "Perancangan Sistem Informasi SDM Berprestasi pada SD Global Surya," in Prosiding Seminar Nasional Darmajaya, 2018, vol. 1, no. 1, pp. 289-294. 